УДК 575.162:599.323.43

\title{
ПОЛИМОРФИЗМ ЦИТОХРОМА Ь КРАСНОЙ ПОЛЕВКИ CLETHRIONOMYS RUTILUS PALLAS
}

\author{
Переверзева В. В., Докучаев Н. Е., Примак А. А., Дубинин Е. А. \\ ФГБУН Институт биологических проблем Севера ДВО РАН, г. Магадан \\ E-mail: vvpereverzeva@mail.ru
}

\begin{abstract}
Проведен анализ полиморфизма участка полипептида цитохрома b красной полевки Clethrionomys rutilus из популяций Северного Приохотья, включая прилежащие острова, и бассейна p. Колыма. В исследованных выборках рассчитаны частоты изоформ цитохрома b. В структуре энзима обнаружены консервативные аминокислотные замены $(\mathrm{mc}=1-\mathrm{mc}=3 ; \mathrm{z}>3.09$; $\mathrm{P}<0.001)$, определена их локализация и степень консервативности. Проведенный анализ свидетельствует о действии стабилизирующего отбора, направленного на сохранение десяти физико-химических свойств у ряда вариантов полипептида.
\end{abstract}

Ключевые слова: красная полевка, Clethrionomys rutilus, ген цитохрома b (cytb), изоформы фермента цитохрома b (Cytb), генетическое разнообразие, филогенетический анализ.

DOI: $10.34078 / 1814-0998-2020-3-109-119$

\section{ВВЕДЕНИЕ}

Красная полевка (Clethrionomys rutilus Pallas, $1779)$ - голарктический вид, ареал которого занимает обширные, преимущественно северные территории Евразии и Северной Америки (Shenbrot, Krasnov, 2005). Пределы Северо-Восточной Азии (CBA) красная полевка населяла уже в раннем плейстоцене (Шер и др., 1977). Во времена средне- и позднеплейстоценовых оледенений большая часть территории СВА, по-видимому, была непригодна для проживания $\mathrm{Cl}$. rutilus. В такие эпохи ареал вида смещался на юг. При этом полевки могли сохраняться в отдельных рефугиумах, из которых в межледниковья вновь заселяли свободные северные территории.

Согласно палеонтологическим данным (Агаджанян, 1980), в каргинское межледниковье лесные (рыжие) полевки уже населяли долину p. Майн (правого притока р. Анадырь). Вероятней всего, это была красная полевка. Причем в отложениях едомной и алешкинской свит Колымы и в отложениях Чаунской равнины остатки рыжих полевок не были найдены (Там же). В последовавшее затем сартанское оледенение северные границы ареала $\mathrm{Cl}$. rutilus сместились на юг. На Северо-Востоке Азии максимум последнего похолодания полевки переживали в рефугиумах на Камчатке и на Охотском побережье. Оледенение также привело к понижению уровня Мирово-

(C) Переверзева В. В., Докучаев Н. Е., Примак А. А., Дубинин Е. А., 2020 го океана. На месте Берингова пролива образовалась суша - так называемый Берингийский мост, соединивший Чукотку и Аляску. С окончанием оледенения красная полевка вновь заселила бассейн Анадыря, откуда по сохранявшемуся какоето время «Берингийскому мосту» проникла на Аляску. Позднеплейстоценовое заселение Аляски красной полевкой признается большинством исследователей (Rausch, 1963; Чернявский, 1984; Cook et al., 2004; Kohli et al., 2015).

При исследованиях филогеографии различных видов млекопитающих используются данные о полиморфизме нуклеотидной последовательности гена cytb (Bannikova et al., 2010; Pacпопова, Щипанов, 2011; Abramson et al., 2012; Koh et al., 2012; Dabrowski et al., 2013; Малярчук и др., 2015; Kohli et al., 2015; Григорьева и др., 2018; Ялковская и др., 2018). Ряд авторов, основываясь на данных об изменчивости нуклеотидной последовательности гена $c y t b$ мтДНК красной полевки, выделили у этого вида для материковых частей суши три основные филогруппы (Iwasa et al., 2002; Abramson, Bodrov, 2008; Maлярчук, 2011; Kohli et al., 2015). Мы придерживаемся классификации, предложенной Н. И. Абрамсон и С. Ю. Бодровым (Abramson, Bodrov, 2008), которые обозначили данные генетические линии Cl. rutilus как западная (3), восточная (В) и берингийская (Б).

Ранее на основании полиморфизма нуклеотидной последовательности фрагмента гена $c y t b$ нами был проведен анализ особенностей гене- 
тической структуры и филогенетических связей ряда популяций красной полевки Северного Приохотья и бассейна р. Колыма (Переверзева и др., 2011, 2013а, б). Было установлено, что часть мутаций обусловливает изменение аминокислотной последовательности, вследствие чего под действие отбора попадают различные варианты белка цитохрома b (Cytb). Энзим Суtb является важным звеном метаболизма и относится к трансмембранным ферментам. Суtb имеет два окислительно-восстановительных центра: Qo связан с внешней поверхностью мембраны митохондрии, Qi - с внутренней. Сравнительный анализ строения молекулы Суtb многих видов животных показал, что трансмембранные домены наиболее вариабельны, а петлевые участки активного центра Qo - самые консервативные (Kocher et al., 1989; McClellan et al., 2005). Было выдвинуто предположение, что адаптивная эволюция митохондриальных ферментов, основанная на изменении биоэнергетики митохондрий, может определять вектор внутривидовой дифференциации (Gershoni et al., 2009). Позже было показано (Maлярчук, 2011), что процесс внутривидовой дивергенции довольно редко сопровождается радикальными аминокислотными заменами, возникающими в Cytb у некоторых видов северных животных под влиянием адаптации. Исследование красных полевок из различных географических точек выявило отсутствие у них аминокислотных замен, свидетельствующих об адаптивных изменениях Cytb. Присутствие у этого вида только консервативных замен указывает на влияние стабилизирующего отбора, поддерживающего структуру данного белка (Малярчук, 2011).

Таблица 1. Количество красных полевок- носителей вариантов F2-F14 участка полипептида цитохрома b в выборках из популяций бассейна р. Колыма и Северного Приохотья

Table 1. The number of the Northern Red-backed vole carriers of F2-F14 variants of the cytochrome b polypeptide site in samples from the populations of the Kolyma River basin and Northern Priokhotye

\begin{tabular}{|l|c|c|}
\hline \multicolumn{1}{|c|}{ Локальность } & $\begin{array}{c}\text { Объем } \\
\text { выборок из } \\
\text { популяции }\end{array}$ & $\begin{array}{c}\text { Количество носителей } \\
\text { изоформ энзима F2-F14 }\end{array}$ \\
\hline Бассейн р. Колыма & 171 & 28 \\
\hline \multicolumn{2}{|c|}{ Материковое побережье Северного Приохотья } \\
\hline Окрестности г. Магадан & 25 & 8 \\
\hline Полуостров Кони & 5 & 3 \\
\hline Бассейн р. Яма & 27 & 8 \\
\hline \multicolumn{2}{|c|}{ Острова Северного Приохотья } \\
\hline Талан & 64 & 24 \\
\hline Недоразумения & 15 & 14 \\
\hline Спафарьева & 15 & 0 \\
\hline Матыкиль & 38 & 38 \\
\hline Совокупная выборка & 360 & 123 \\
\hline
\end{tabular}

Нами также было установлено, что большинство красных полевок североохотоморского и колымского регионов имеет вариант F1 полипептида Cytb. Был проведен анализ полиморфизма нуклеотидных последовательностей участка гена $c y t b$, кодирующих изоформу Cytb F1 (Переверзева, Примак, 2016). Предварительный анализ показал высокий уровень полиморфизма полипептида Cytb у красных полевок Северного Приохотья и бассейна р. Колыма (Переверзева, Примак, 2015). Настоящее исследование является продолжением изучения генетического разнообразия $\mathrm{Cl}$. rutilus. В предлагаемой работе проводится развернутый анализ полиморфизма аминокислотной последовательности участка фермента Cytb изоформ F2-F14 в некоторых популяциях красной полевки Северного Приохотья и бассейна p. Колыма и сравнение аминокислотной последовательности этого фрагмента у полевок Магаданской области, Европы, Западной Сибири, юга Дальнего Востока и Аляски.

\section{МАТЕРИАЛ И МЕТОДЫ}

Ранее нами был исследован полиморфизм нуклеотидной последовательности фрагмента гена cytb красной полевки (Переверзева и др., 2011, 2013a). В данной работе используется другой методологический подход - на основании программного обеспечения (пакета программ MEGA и TreeSAAP) анализируется полиморфизм аминокислотной последовательности фрагмента полипептида Cytb. Для генетического анализа из общей выборки 360 полевок колымского и приохотского регионов отобраны только образцы с изоформами Cytb F2-F14 (табл. 1). Места отлова красных полевок приведены на картосхеме в одной из наших статей (Переверзева, Примак, 2016). Гаплотипы гена $c y t b$ красных полевок колымского региона и материковой части Северного Приохотья маркированы буквой «В» (восточная генетическая линия), о. Талан - «Т», о. Недоразумения - «Н» и о. Матыкиль - «М».

Для проведения филогенетического анализа, помимо собственных данных, из GenBank были взяты сведения о нуклеотидной последовательности участка гена $c y t b$, кодирующего у полевок берингийской, восточной и западной материнских линий (Iwasa et al., 2002; Cook et al., 2004; Kohli et al., 2015) полипептиды, отличные от варианта, обозначенного нами как F1. Представленные в GenBank изоформы Cytb полевок берингийской клады мы обозначили «F(Б)», восточной $-\langle\mathrm{F}(\mathrm{B}) »$ и западной $-« \mathrm{~F}(3) »$. 
На основании данных о нуклеотидной последовательности фрагмента из 759 пар нуклеотидов гена $c y t b$ определены 253 аминокислоты белка Суtb, соответствующие участку от 128-й до концевой аминокислоты энзима включительно. В работе используется однобуквенное обозначение аминокислот, рекомендуемое ИЮПАК (IUPAC). Картирование анализируемого участка $c y t b$ проводили относительно полной нуклеотидной последовательности мтДНК Clethrionomys regulus (GenBank, № NC016427). В качестве внешней группы использована нуклеотидная последовательность участка гена cytb Craseomys rufocanus Sundevall, 1846 (GenBank, № GQ301944). Топология аминокислотных замен в пространственной конфигурации фрагмента фермента Cytb представлена в соответствии с N. Howell, D. M. Irwin и D. A. McClellan (Howell, 1989; Irwin et al., 1991; McClellan et al., 2005). С помощью пакета программ MEGA 6.0.2.74 (Tamura et al., 2013) определяли сайты несинонимичных нуклеотидных замен и аминокислотные последовательности обнаруженных вариантов полипептида $\mathrm{Cytb}$, проводили филогенетический анализ cytb-гаплотипов. Для детекции филогенетических связей гаплотипов применяли дендрограммы, построенные по методу максимального правдоподобия (ML) на основании бипараметрической модели дистанций Кимуры (Tamura et al., 2013). Оценку узлов ветвления выполняли бутстреп-методом (1000 итераций). Для оценки адаптивности изменений в фрагменте гена $c y t b$ использовали программу TreeSAAP, которая определяет селективные воздействия в процессе кладогенеза на 31 структурное и биохимическое физико-химическое свойство аминокислот с использованием z-теста (Woolley et al., 2003). Это позволяет оценить замены аминокислот в восьми категориях значимости $(\mathrm{mc})$ и определить тип отбора: при стабилизирующем отборе сохраняются консервативные аминокислотные замены $(\mathrm{mc}=$ $1-\mathrm{mc}=3$ при $\mathrm{z}>3.09, \mathrm{P}<0.001)$, а при движущем - радикальные $(\mathrm{mc}=6-\mathrm{mc}=8$ при $\mathrm{z}>3.09$, $\mathrm{P}<0.001)$.

\section{РЕЗУЛЬТАТЫ И ОБСУЖДЕНИЕ}

Проведенные нами ранее исследования изменчивости гена $c y t b$ мтДНК $C l$. rutilus позволили установить, что популяции вида, обитающие в бассейне Колымы и Северном Приохотье (за исключением особей о. Матыкиль), принадлежат к восточной материнской линии. Полевки о. Матыкиль относятся к берингийской генетической ветви (Переверзева и др., 2013а, б). У красных полевок бассейна Колымы обнаружено 57 гаплотипов гена cytb (GenBank, № GQ301890GQ301943, GQ301945-GQ301947), кодирующих восемь (F1-F8) изоформ полипептида Суtb. Об- суждался возможный эволюционный потенциал найденных вариантов фермента (Переверзева и др., 2011). У полевок Северного Приохотья найдено 37 ранее не описанных гаплотипов (GenBank, № JX885743-JX885766, HQ608514HQ608519, HQ840372, GU251073, GU251074, GU251077, GU251085-GU251087) (Переверзева и др., 2013а). Было установлено, что у красных полевок Северо-Востока Азии и Аляски наиболее распространен вариант энзима Cytb F1 (Переверзева, Примак, 2016). У особей $C$. rutilus Ceверного Приохотья и колымского региона, помимо F1, выявлено еще 13 изоформ белка Cytb. B общей сложности, в сумме с представленными в GenBank образцами, определено 35 вариантов аминокислотных последовательностей исследованного фрагмента Сytb (рис. 1).

Частоты полипептидных последовательностей F2-F14 представлены в табл. 2. Обнаружено, что изоформа F4 в колымской популяции является второй по частоте встречаемости после F1. Вариант F5, третий по распространенности у полевок бассейна Колымы, обнаружен также во всех исследованных материковых популяциях Северного Приохотья. Кроме того, изоформа F6, впервые найденная у полевок бассейна Колымы, выявлена и у особей из бассейна р. Яма. В табл. 2 показано, что изоформу полипептида F5 у исследованных полевок магаданского региона кодируют 10 вариантов гена, F4 и F6 - по 3 гаплотипа $c y t b$. Изоформа F12 определяется нуклеотидными последовательностями гена $c y t b$ T2, M1 и M3, обнаруженными у полевок о-вов Талан и Матыкиль. Следует отметить, что о. Талан населяют особи восточной материнской линии, а o. Матыкиль - берингийской. В базе данных GenBank нами найдены cytb-гаплотипы, кодирующие у полевок ряд изоформ энзима (см. рис. 1), в том числе у особей берингийской клады варианты полипептида Cytb F4-F6 и F12. Кроме того, в GenBank были обнаружены $c y t b$-гаплотипы, которые кодируют у полевок западной и берингийской клад одинаковую аминокислотную последовательность, обозначенную нами как F(3)1.

На рис. 2 показаны нуклеотидные замены в гаплотипах, кодирующих у красных полевок изоформы Cytb F4-F6, F12 и F(3)1. Варианты гена F4-cytb разнятся между собой 22, F5-cytb - 30, F6-cytb - 16, F12-cytb - 20 и F(3)1-cytb - 21-й нуклеотидными заменами соответственно. Полученные результаты позволяют говорить о дивергенции нуклеотидной структуры гена $c y t b$, которая сопровождается конвергенцией аминокислотной последовательности фермента Суtb к данным вариантам полипептида.

Кроме F1, F5 и F6, у полевок Северного Приохотья найдены изоформы F9-F14. В популяции полевок бассейна р. Яма обнаружены ва- 


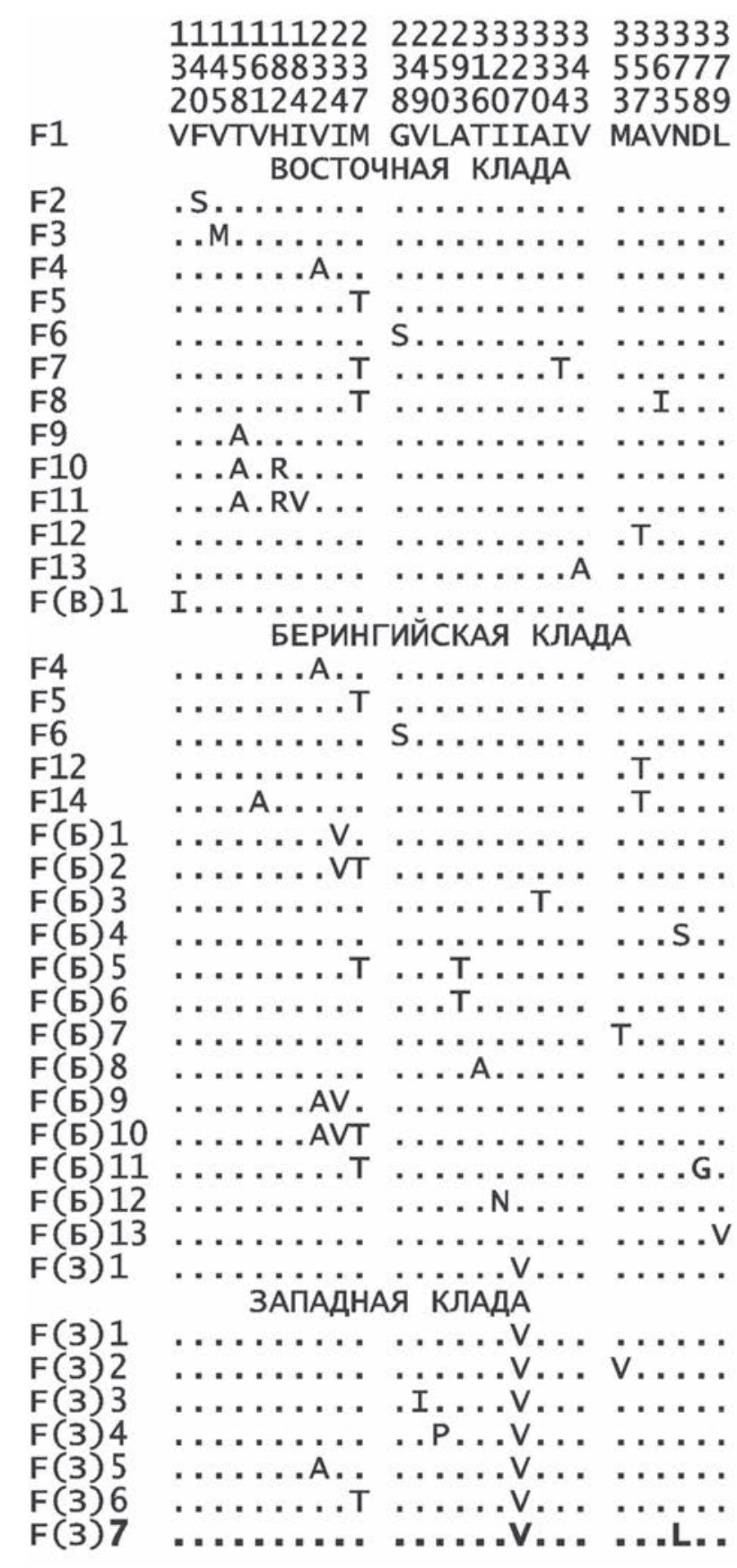

Puc. 1. Аминокислотные замены в изоформах фрагмента полипептида цитохрома b у красных полевок восточной, берингийской и западной филетических линий. Замены представлены относительно аминокислотной последовательности варианта F1. Сайты замен показаны от начала полипептида цитохрома $\mathrm{b}$

Fig. 1. Amino acid substitutions in isoforms of the cytochrome $\mathrm{b}$ polypeptide fragment in the Northern redbacked voles of the eastern, Bering, and western phyletic lines. Substitutions are represented relative to the amino acid sequence of variant F1. Substitution sites are shown from the beginning of the cytochrome b polypeptide

рианты F9-F11. Большинство особей Cl. rutilus о. Недоразумения имеют уникальный полипептид F13. По всей видимости, это иллюстриру- ет результат синергии дрейфа генов и эффекта основателя на генофонд небольшой изолированной популяции.

Результаты кластерного анализа гаплотипов $c y t b$, кодирующих у красных полевок различные изоформы фермента Cytb (F2-F14 и варианты аминокислотных последовательностей образцов, представленных в GenBank), приведены на рис. 3. Наличие трех крупных кластеров с высокими значениями бутстреп-индексов обусловлено генетической обособленностью восточной, берингийской и западной материнских линий красной полевки. Кластеры полиморфны по структуре и подразделяются на субкластеры, часть из которых имеет значимые бутстрепиндексы в узлах ветвей. Варианты $c y t b$, определяющие аминокислотную структуру изоформ F4-F6 и F12 (на рис. 3 отмечены *), относятся к разным субкластерам берингийской и восточной клад (рис. 3). Генетическая дифференциация этих гаплотипов подтверждается высокими значениями соответствующих бутстреп-индексов, что также указывает на дивергенцию нуклеотидных последовательностей этих вариантов мтДНК.

Проведен TreeSAAP-анализ всех cytbгаплотипов, включая все варианты мтДНК, кодирующие F1. Выявлены достоверные изменения десяти свойств белка ( $\mathrm{z}>3.09 ; \mathrm{P}<0.001)$ у вариантов полипептида F2, F4, F11, F12, F14, $\mathrm{F}(3) 2$ и $\mathrm{F}(3) 5$ (бутстреп-индексы 95, 98, 82, 73, $99,66,67$ соответственно) полевок восточной и западной генетических ветвей. Значение индекса бутстреп-поддержки ветви всех гаплотипов полевок западной клады составляет 79. Следует отметить, что аминокислотные замены в перечисленных вариантах энзима характеризуются категориями значимости $\mathrm{mc}=1-\mathrm{mc}=3$ (табл. 3 ), что соответствуют консервативному типу замен. Можно предположить, что закрепление мутаций, приводящих к указанным изоформам энзима, в генофондах популяций вида произошло в результате действия стабилизирующего отбора. Кроме того, аминокислотные замены в полипептидах F5 и F6 также являются консервативными (mc = $1-\mathrm{mc}=3)$. Однако значение бутстреп-индексов ветвей ML-дерева, на которых расположены кодирующие их $c y t b$-гаплотипы, менее 50.

Аминокислотные замены в найденных вариантах энзима Cytb относительно F1 представлены на рис. 1. Изоформы данного фермента отличаются от варианта F1 от одной до трех аминокислотных замен. Известно, что замена аминокислоты в молекуле фермента не всегда приводит к его инактивации: консервативные замены в активном центре оказывают незначительное влияние на активность фермента, а участки вне активного центра могут претерпевать серьез- 
Таблица 2. Частота вариантов полипептида цитохрома b F2-F14 в выборках из популяций красной полевки Северного Приохотья и бассейна р. Колыма

Table 2. The frequency of cytochrome b F2 - F14 polypeptide variants in samples from Northern Red-backed vole populations ofe Northern Priokhotye and the Kolyma River basin

\begin{tabular}{|c|c|c|c|}
\hline $\begin{array}{c}\text { Вариант } \\
\text { полипептида }\end{array}$ & Гаплотипы гена cytb & Локальность & $\begin{array}{c}\text { Частота } \\
\text { полипептида }\end{array}$ \\
\hline $\mathrm{F} 2$ & B54 & Бассейн р. Колыма & 0.0058 \\
\hline F3 & B20 & То же & 0.0058 \\
\hline F4 & $\mathrm{B} 50, \mathrm{~B} 52, \mathrm{~B} 53$ & $-"-$ & 0.0876 \\
\hline \multirow{4}{*}{ F5 } & $\mathrm{B} 25, \mathrm{~B} 27, \mathrm{~B} 28, \mathrm{~B} 32, \mathrm{~B} 49$ & $-"-$ & 0.0349 \\
\hline & B61, B62, B68 & Окрестности г. Магадан & 0.3200 \\
\hline & B62, B66 & Бассейн р. Яма & 0.1111 \\
\hline & B82 & Полуостров Кони & 0.6000 \\
\hline \multirow{2}{*}{ F6 } & B29, B30 & Бассейн р. Колыма & 0.0175 \\
\hline & B30, B81 & Бассейн р. Яма & 0.0740 \\
\hline F7 & B48 & Бассейн р. Колыма & 0.0058 \\
\hline F8 & B26 & То же & 0.0058 \\
\hline F9 & $\mathrm{B} 70$ & Бассейн р. Яма & 0.0370 \\
\hline F10 & B76 & То же & 0.0740 \\
\hline F11 & B80 & $-"-$ & 0.0370 \\
\hline \multirow{2}{*}{ F12 } & $\mathrm{T} 2$ & о. Талан & 0.3750 \\
\hline & $\mathrm{M} 1 *, \mathrm{M} 3 *$ & о. Матыкиль & 0.9737 \\
\hline F13 & H1 & о. Недоразумения & 0.9333 \\
\hline F14 & M2* & о. Матыкиль & 0.0263 \\
\hline
\end{tabular}

*Отмечены гаплотипы красных полевок берингийской материнской линии.

ные изменения без потери функции энзима (Диксон, Уэбб, 1982). Поэтому была проанализирована локализация сайтов аминокислотных замен в структуре энзима Cytb для исследуемых вариантов полипептида. В табл. 3 показана степень консервативности, локализация в полипептиде Cytb и категории значимости (mc) аминокислотных замен. Полученные результаты свидетельствуют о наличии у красной полевки сайтов замен в полипептиде Cytb не только в вариабельных и промежуточных по степени консервативности точках, но и в петлевом участке cd1-helix активного центра Qо - наиболее консервативной части фермента. Аминокислотных замен в вариабельных сайтах и в участках промежуточной консервативности выявлено на порядок больше, чем в консервативных точках. Найдены одинаковые аминокислотные замены у красных полевок разных генетических линий. Данные рис. 1 и табл. 3 показывают локализацию в вариабельном сайте трансмембранного домена Е замещения V232A, обнаруженного у экземпляров восточной (F4), берингийской $(\mathrm{F}($ Б) $9, \mathrm{~F}($ Б)10) и западной $(\mathrm{F}(3) 5)$ генетических клад. В вариабельном участке этого же домена присутствует замена М237Т, найденная у особей восточной (F5, F7, F8), берингийской $(\mathrm{F}($ Б $) 2, \mathrm{~F}($ Б) $5, \mathrm{~F}($ Б) $10, \mathrm{~F}($ Б) 11$)$ и западной
(F(3)6) генетических ветвей. Особо следует отметить наличие у всех представителей западной линии V 327 , а у особей восточной и берингийской (за исключением одного образца) ветвей - I327. Этот сайт расположен в трансмембранном домене $\mathrm{G}$ и является промежуточным по степени вариабельности (Howell, 1989). TreeSAAP-анализ $(\mathrm{mc}=1$ при $\mathrm{z}>3.09, \mathrm{P}<0.001 ; \beta$-структура) свидетельствует о консервативном характере данной замены. По-видимому, при расхождении материнских линий у предковых особей западной клады закрепился вариант V327, а у берингийской и восточной - I327 (cм. рис. 1). Валин и изолейцин являются моноаминомонокарбоновыми кислотами с близкими по свойствам алифатическими радикалами (Химическая..., 1988). Возникновение у родоначальников генетических клад мутации A979G (см. рис. 1) в гене $c y t b$ произошло, вероятно, случайно. Закреплению вариантов V 327 и I327 в разных материнских линиях полевок способствовал стабилизирующий отбор. По-видимому, V327 может претендовать на роль молекулярного маркера красных полевок западной материнской линии.

Наличие полиморфизма и дивергенции нуклеотидной последовательности гена cytb, coпряженной с конвергенцией к полипептидным 


$\begin{array}{ll} & \\ \text { B1 GQ301890 } & \\ & \\ \text { B50 } & \text { GQ301939 } \\ \text { B52 } & \text { GQ301941 } \\ \text { B53 } & \text { GQ301942 } \\ \text { KJ789517 } & \\ \text { KJ785 } & \\ & \\ \text { B25 } & \text { GQ301914 } \\ \text { B27 } & \text { GQ301916 } \\ \text { B28 } & \text { GQ301917 } \\ \text { B32 GQ301921 } & \text { GQ301938 } \\ \text { B49 } & \text { GQ301938 } \\ \text { B61 JX885746 } & \text { J } 885747 \\ \text { B62 JX885747 } & \text { JX885751 } \\ \text { B66 } & \text { JX88575 } \\ \text { B68 } & \text { JX885753 } \\ \text { B82 } & \text { HQ608518 }\end{array}$

KJ789537
KJ789538
KJ789483
KJ789515
KJ556622
KJ78952
KJ789572
KJ789574

B29 GQ301918

B30 GQ301919

B81 JX885766

F430949

T2 GU251087

M1 GU251073 M3 GU251074 KJ789506

\section{KJ789504}

KJ789494

KJ789585

KJ789595

KJ789597

KJ789593

KJ789526

KJ789543

KJ789544
AB072218

AY309428

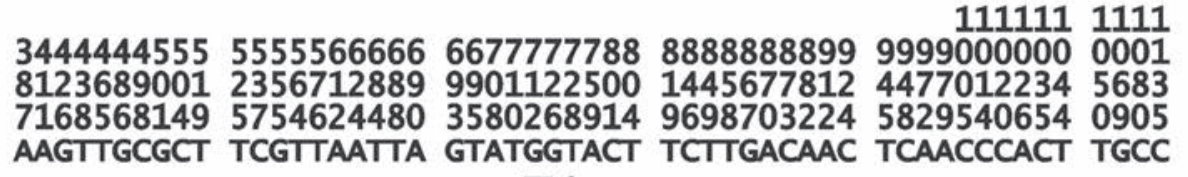

F4

ВОСТОЧНАЯ КЛАДА

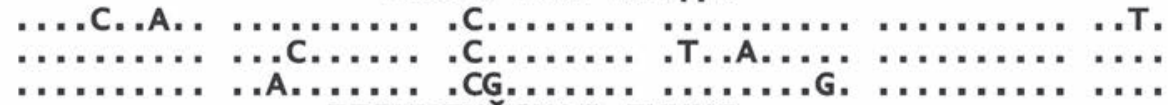

БЕРИНГИЙСКАЯ ЛИНИЯ

.G...ATC.. .......ССT .СG....G.. .........T C.G...T... ...

\section{F5}

\section{ВОСТОЧНАЯ КЛАДА}

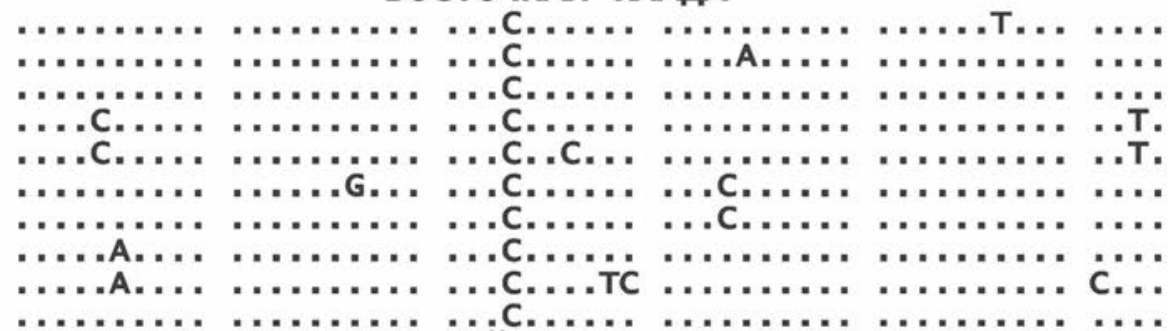

БЕРИНГИЙСКАЯ КЛАДА

.G. . .ATC. . .....G.CCG ..GC...G.. ..C..C.... C.G......... .

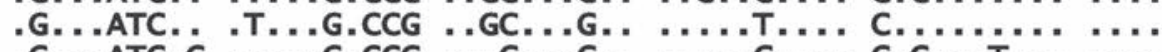
.G...ATC.C ........CCG ...C...G.......... C.G.......... . .G...ATC.. C....G.CCG ...C...G........... C.G...T......

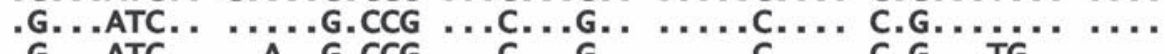
.G...ATC.. .A..G.CCG ...C...G. ......... C.G..TG..... .

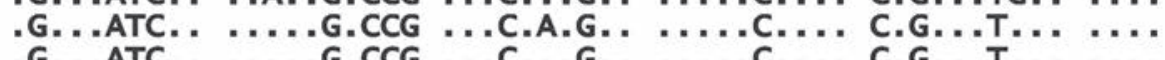
.G...ATC.......G.CCG ...C...G.......... C.G......... F6

\section{ВОСТОЧНАЯ КЛАДА}

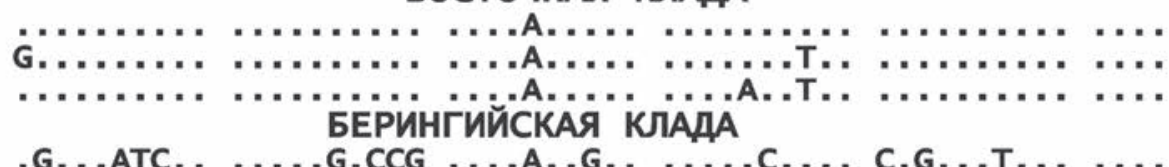

F12

ВОСТОЧНАЯ КЛАДА БЕРИНГИЙСКӒ̆ КЛ̈̈Д̈̈

.GA..AG... ...C.G.CCG …...... …..... C.G........ ..T

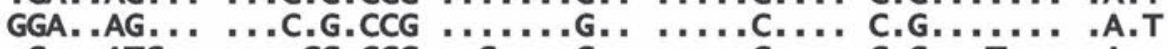
.G...ATC.. ....CG.CCG ..G...G........... C.G...T... .A..

F(3) 1

БЕРИНГИЙСКАЯ КЛАДА

.G. . .ATC. . .....G.CC. ..G....G. . . . . ... C.GG. .T. . . . . ЗАПАДНАЯ КЛАДА

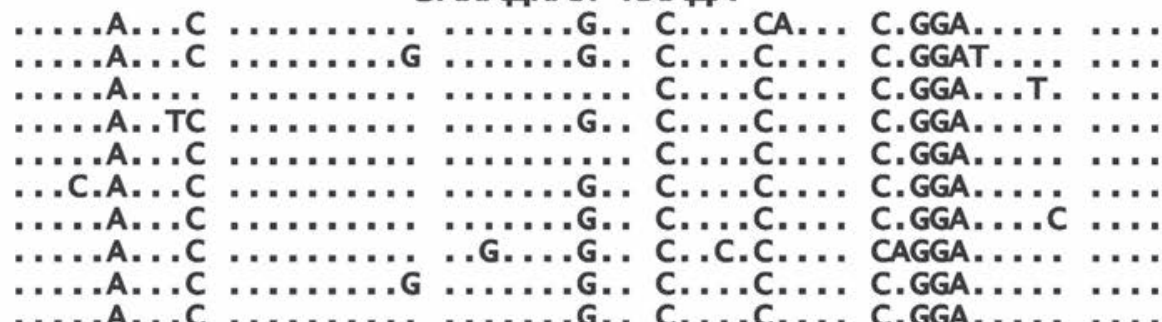

Puc. 2. Гаплотипы фрагмента гена цитохрома $b$ F4-, F5-, F6-, F12- и F(3)1 - особей красной полевки восточной, берингийской и западной филетических линий. Нуклеотидные замены представлены относительно последовательности варианта В1. Сайты замен показаны от начала гена цитохрома $b$

Fig. 2. Haplotypes of the cytochrome $b$ gene fragment of F4, F5, F6, F12 and F(3)1 individuals of the northern redbacked vole of the eastern, Bering and western phyletic lines. Nucleotide substitutions are represented relative to the variant B1 sequence. Substitution sites are shown from the beginning of the cytochrome $b$ gene 
Puc. 3. ML-филогенетическое дерево, построенное по данным об изменчивости фрагмента гена цитохрома $b$ мтДНК красной полевки берингийской (БК), западной (ЗК) и восточной (ВК) генетических клад, кодирующих различные изоформы аминокислотной последовательности F. В узлах ветвления указаны бутстреп-индексы (> $50 \%$ ). Варианты $c y t b$, детерминирующие аминокислотное строение F4-F6 и F12, отмечены *

Fig. 3. ML-phylogenetic tree constructed from data on the variability of the mtDNA cytochrome $b$ gene fragment of the Beringian (БК), Western (ЗК) and Eastern (BK) genetic clades of the Northern Red-backed vole encoding various isoforms of the amino acid sequence F. Bootstrap indexes $(>50 \%)$ are indicated in the branching nodes. Cytb variants that determine the amino acid structure of the isoforms F4-F6 and F12 are marked with *

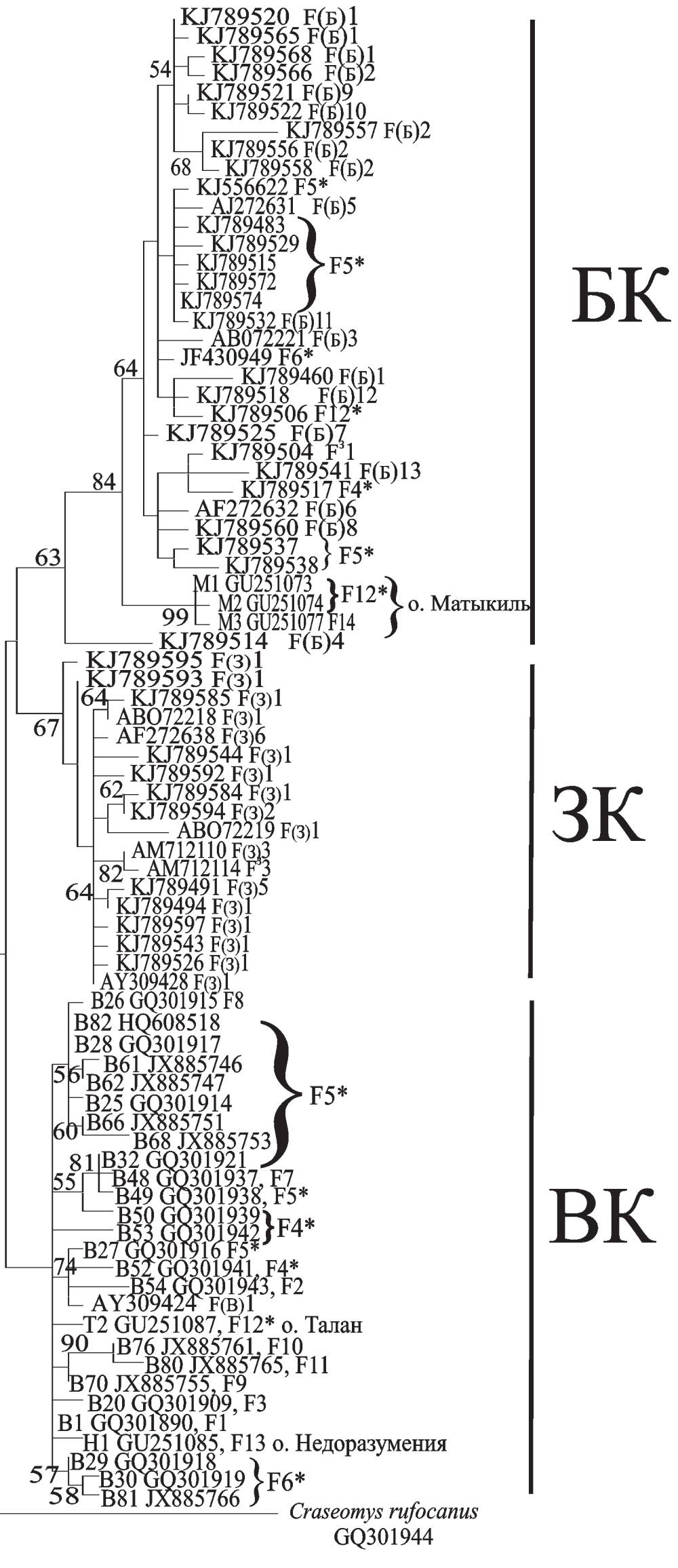


Таблица 3. Степень консервативности, локализация сайта и уровень значимости аминокислотных замен в изоформах полипептида цитохрома b у красной полевки

Table 3. The degree of conservatism, site localizationo and level of significance of amino acid substitutions in isoforms of the cytochrome b polypeptide in the Northern Red-backed vole

\begin{tabular}{|c|c|c|}
\hline $\begin{array}{c}\text { Степень } \\
\text { консервативности }\end{array}$ & Участок энзима & Вариант полипептида \\
\hline \multirow{4}{*}{ Консервативный } & Трансмембранный домен C & $\mathrm{F}(\mathrm{B}) 1$ \\
\hline & Qo, cd 1-helix & $\mathrm{F} 2 *(\mathrm{mc}=3), \mathrm{F} 3$ \\
\hline & Трансмембранный домен D & F10, F11 \\
\hline & Трансмембранный домен F & $\mathrm{F}(\mathrm{Б}) 5, \mathrm{~F}(\mathrm{Б}) 6$ \\
\hline \multirow{4}{*}{ Промежуточный } & Qo, cd 2-helix & $\mathrm{F} 9, \mathrm{~F} 10, \mathrm{~F} 11 *(\mathrm{mc}=1), \mathrm{F} 14$ \\
\hline & Трансмембранный домен G & $\mathrm{F} 13 ; \mathrm{F}($ Б$) 8, \mathrm{~F}($ Б$) 12 ; \mathrm{F}(3) 1 *-\mathrm{F}(3) 7 *(\mathrm{mc}=1)$ \\
\hline & Трансмембранный домен Н & $\begin{array}{l}\mathrm{F} 8, \mathrm{~F} 12 *(\mathrm{mc}=2-3), \mathrm{F} 14 *(\mathrm{mc}=2-3) ; \mathrm{F}(\mathrm{Б}) 7 \\
\mathrm{~F}(3) 2 *(\mathrm{mc}=2), \mathrm{F}(3) 7\end{array}$ \\
\hline & С-конец & $\mathrm{F}($ Б$) 4, \mathrm{~F}(Б) 11, \mathrm{~F}($ Б $) 13$ \\
\hline \multirow[t]{2}{*}{ Гипервариабельный } & Трансмембранный домен Е & $\begin{array}{l}\mathrm{F} 4 *(\mathrm{mc}=2-3), \mathrm{F} 5-\mathrm{F} 8 ; \mathrm{F}(\text { Б }) 1, \mathrm{~F}(\text { Б }) 2, \mathrm{~F}(\text { Б }) 5 \\
\mathrm{~F}(\text { Б }) 9-\mathrm{F}(\text { Б) } 11 ; \mathrm{F}(3) 3 *(\mathrm{mc}=1), \mathrm{F}(3) 4 \\
\mathrm{F}(3) 5 *(\mathrm{mc}=2-3), \mathrm{F}(3) 6\end{array}$ \\
\hline & Трансмембранный домен G & $\mathrm{F} 7, \mathrm{~F}($ Б)3 \\
\hline
\end{tabular}

Примечание. Варианты цитохрома b красных полевок с консервативным типом аминокислотных замен (mc - уровень значимости при z > 3.09; P < 0.001) и бутстреп-индексами на концах ветвей более 50 отмечены звездочкой. Петлевые участки фермента - cd1-helix, cd2-helix; Qo - активный центр, связанный с внешней мембраной митохондрии.

последовательностям F4, F5, F6 и F12, можно объяснить особенностями биологии красной полевки. Высокие темпы размножения и быстрая смена поколений способствуют фиксации большого числа независимо возникших мутаций. Вырожденность генетического кода обусловливает закрепление в генофонде популяций различных генотипов, детерминирующих одинаковые витальные фенотипы. Результаты проведенного анализа свидетельствуют о стохастической природе разнообразия гена cytb и конвергентном происхождении некоторых изоформ цитохрома b. Совокупное действие двух эволюционных факторов - высокой мутабильности и стабилизирующего отбора - может обусловливать наблюдаемый у красной полевки феномен сопряжения полиморфизма и дивергенции структуры гена $c y t b$ с конвергенцией к полипептидам F4, F5, F6 и F12 энзима Cytb. По-видимому, появление в популяциях полевок полиморфных F4-, F5-, F6-, F12-мтДНК-гаплотипов случайно, а закрепление - закономерно. Фермент Сytb является ключевым звеном системы клеточного дыхания, и его структура должна быть жестко детерминирована прессингом стабилизирующего отбора. Аминокислотные замены, обусловливающие различные варианты Cytb, найдены как в петлевых участках активного центра фермента, так и в трансмембранных доменах. Анализ достоверно подтверждает только консервативный тип аминокислотных замен. По всей видимости, стабилизирующий отбор отсекал все формы по- липептида, значительно понижающие функциональную эффективность энзима.

Работа выполнена при частичной поддержке гранта РФФИ № 18-04-00579а.

\section{ЛИТЕРАТУРА}

Агаджанян A. К. Фауна млекопитающих плейстоцена Чукотки и основные этапы ее формирования // Новейшие отложения и палеогеография плейстоцена Чукотки. Москва : Наука, 1980. С. 256-268.

Григорьева О. О., Стахеев В. В., Орлов В. Н. Митохондриальные свидетельства прошлого рефугиального распространения малой лесной мыши Sylvaemus uralensis Pall. (RODENTIA, MURIDAE) на северозападном Кавказе // Генетика. 2018. Т. 54, № 3. С. 326334.

Диксон М., Уэбб Э. Ферменты. Москва : Мир, 1982. T. 2. С. $735-768$.

Малярчук Б. А. Адаптивная внутривидовая дивергенция (на примере гена цитохрома $b$ животных) // Генетика. 2011. Т. 47, № 8. С. 1103-1111.

Малярчук Б. А., Деренко М. В., Денисова Г. А. Изменчивость митохондриального генома росомахи (Gulo gulo) // Там же. 2015. Т. 51, № 11. С. 12911296.

Переверзева В. В., Засыпкин М. Ю., Соловенчук Л. Л., Примак А. А., Дубинин Е. А. Изменчивость гена цитохрома $b$ митохондриальной ДНК в популяции красной полевки Clethrionomys rutilus Pallas, 1779 поймы среднего течения реки Колымы // Известия РАН. Сер. биол. 2011. № 3. С. 283-288.

Переверзева В. В., Примак А. А. Генетический анализ полиморфизма участка фермента цитохрома $b$ красной полевки Myodes rutilus Pallas, 1779 // Чтения 
памяти акад. К. В. Симакова : Материалы докл. Всерос. науч. конф. (Магадан, 24-25 нояб. 2015 г.). Магадан : СВНЦ ДВО РАН, 2015. С. 148-149.

Переверзева В. В., Примак А. А. Генетическое разнообразие синонимичных гаплотипов фрагмента гена цитохрома $b$ красной полевки Myodes (Clethrionomys) rutilus Pallas, 1779 // Генетика. 2016. Т. 52, № 2. С. 189-197.

Переверзева В. В., Примак А. А., Дубинин Е. А. Генетическая структура популяций красной полевки Myodes (= Clethrionomys) rutilus Pallas, 1779 Северного Приохотья по данным об изменчивости нуклеотидных последовательностей гена цитохрома $b$ митохондриальной ДНК // Вавиловский журнал генетики и селекции. 2013а. Т. 17, № 3. С. 435-443.

Переверзева В. В., Примак А. А., Дубинин Е. А. Филогенетические отношения популяций красной полевки Myodes (= Clethrionomys) rutilus Pallas, $1779 \mathrm{Ce}-$ верного Приохотья и Колымского региона // Там же. 2013б. Т. 17, № 3. С. 444-451.

Распопова A. А., Щипанов Н. А. Изменчивость участка цитохрома $b$ в разных хромосомных расах и популяциях обыкновенной бурозубки Sorex araneus L., 1758 // Генетика. 2011. T. 47, № 4. C. 527-536.

Химическая энииклопедия / под ред. И. Л. Кнунянц. Москва : Сов. энциклопедия, 1988. Т. 1. 623 с.

Чернявский $\Phi$. Б. Млекопитающие крайнего северо-востока Сибири. Москва : Наука, 1984. 392 с.

Шер А. В., Гитерман Р. Е., Зажигин В. С., Киселев $C$. $B$. Новые данные о позднекайнозойских отложениях Колымской низменности // Известия АН СССР. Сер. геол. 1977. № 5. С. 69-83.

Ялковская Л. Э., Зыков С. В., Сибиряков П. А. Генетическая изменчивость желтогорлой мыши (Sylvaemus flavicollis Melch., 1834, MURIDAE, RODENTIA) на восточной границе ареала // Генетика. 2018. Т. 54, № 6. C. 629-638.

Abramson N. I., Bodrov S. Yu. Genetic differentiation and phytogeography of Clethrionomys rutilus Pallas, 1811 inferred from variation of mitochondrial cytochrome $\mathrm{b}$ gene $/ 11^{\text {th }}$ International conference "Rodens et Spatium" on Rodent Biology. Myshkin, Russia, July 2428. Moscow : VTO RAS, 2008. P. 64.

Abramson N. I., Petrova T. V., Dokuchaev N. E., Obolenskaya E. V., Lissovsky A. A. Phylogeography of the Gray Red-backed Vole Craseomys rufocanus (Rodentia: Cricetidae) across the distribution range inferred from nonrecombining molecular markers // Russian Journal of Theriology. 2012. Vol. 11, No. 2. P. 137-156.

Bannikova A. A., Dokuchaev N. E., Yudina E. V., Bobretzov A. V., Sheftel B. I., Lebedev V. S. Holarctic phylogeography of the tundra shrew (Sorex tundrensis) based on mitochondrial genes // Biological Journal of the Linnean Society. 2010. Vol. 101, No. 3. P. 721-746.

Cook J. A., Runck A. M., Conroy C. J. Historical biogeography at the crossroads of the northern continents: molecular phylogenetics of red-backed voles (RODENTIA: Arvicolinae) // Molecular Phylogenetics and Evolution. 2004. Vol. 30. P. 767-777.
Dąbrowski M. J., Pomorski J. J., Gliwicz J. Cytochrome $b$ gene (cytb) sequence diversity in a Microtus oeconomus population from Białowieża Primeval Forest // Acta Theriologica. 2013. Vol. 58, No. 2. P. 119 126.

Gershoni M., Templeton A. R., Mishmar D. Mitochondrial bioenergetics as a major motive force of speciation // Bioessays. 2009. Vol. 31. P. 642-650.

Howell $N$. Evolutionary conservation of protein regions in the proton motive cytochrome $b$ and their possible roles in redox catalysis // Journal of Molecular Evolution. 1989. Vol. 29. P. 157-169.

Irwin D. M., Kocher T. D., Wilson A. C. Evolution of the cytochrome $b$ gene of mammals // Ibid. 1991. Vol. 32. P. 128-144.

Iwasa M. A., Kartavtseva I. V., Dobrotvorsky A. K., Panov V. V., Suzuki H. Local differentiation of Clethrionomys rutilus in northeastern Asia inferred from mitochondrial gene sequences // Mammalian Biology. 2002. Vol. 67. P. 157-166.

Kocher T. D., Thomas W. K., Meyer A., Edwards S. V., Paado S., Villablanca F. X., Wilson A. C. Dynamics of mitochondrial DNA evolution in animals: Amplification and sequencing with conserved primers // Proceedings of the National Academy of Sciences of the United States of America. 1989. Vol. 86. P. 6196-6200.

Koh H. S., Jang K. H., In S. T., Han E. D., Jo J. E., Ham E. J., Jeong S. K., Lee J. E., Kim K. S., Kweon G. H. Genetic distinctness of Sorex caecutiens hallamontanus (Soricomorpha: MAMMALIA) from Jeju island in Korea: cytochrome oxidase I and cytochrome b sequence analyses // Animal Systematics, Evolution and Diversity. 2012. Vol. 28, No. 3. P. 215-219.

Kohli B. A., Fedorov V. B., Waltari E., CookJ. A. Phylogeography of a Holarctic rodent (Myodes rutilus): testing high-latitude biogeographical hypotheses and the dynamics of range shifts // Journal of Biogeography. 2015. Vol. 42, No. 2. P. 377-389.

McClellan D. A., Palfreyman E. J., Smith M. J., Moss J. L., Christensen R. G., Sailsbery J. K. Physicochemical evolution and molecular adaptation of the cetacea and artiodactyla cytochrome b proteins // Molecular Biology and Evolution. 2005. Vol. 22. P. 437-455.

Rausch R. L. A review of the distribution of Holarctic recent mammals / A Symposium, $10^{\text {th }}$ Pacific Science Congress, Honolulu, Hawaii, 1961 / ed. J. Linsley Gressitt. Bishop Museum Press, 1963. P. 29-43.

Shenbrot G. I., Krasnov B. R. An atlas of the geographic distribution of the arvicoline rodents of the world (Rodentia, Muridae: Arvicolinae). Sofia : Pensoft Publishing, 2005. 336 p.

Tamura K., Stecher G., Peterson D., Filipski A., Kumar S. MEGA-6: Molecular Evolutionary Genetics Analysis Version 6.0.2.74 // Molecular Biology and Evolution. 2013. Vol. 30. P. 2725-2729.

Woolley S., Johnson J., Smith M. J., Grandall K. A., McClellan D. A. TreeSAAP: Selectionon Amino Acid Properties using phylogenetic trees // Bioinformatics. 2003. Vol. 19, No. 5. P. 671-672. 


\title{
CYTOCHROME b POLYMORPHISM OF THE NORTHERN RED-BACKED VOLE CLETHRIONOMYS RUTILUS PALLAS
}

\author{
V. V. Pereverzeva, N. E. Dokuchaev, A. A. Primak, E. A. Dubinin \\ Institute of Biological Problems of the North, FEB RAS, Magadan
}

\begin{abstract}
Polymorphism of the cytochrome b polypeptide segment of the Northern Red-backed Vole Clethrionomys rutilus from populations of Northern Priokhotye, including adjacent islands and the Kolyma river basin, was analyzed. The frequencies of cytochrome $b$ isoforms in the studied samples were calculated. Conservative amino acid substitutions were found in the enzyme structure $(\mathrm{mc}=$ $1-\mathrm{mc}=3 ; \mathrm{z}>3.09 ; \mathrm{P}<0.001)$, their localization and degree of conservatism were determined. The analysis shows the effect of stabilizing selection aimed at preserving ten physical and chemical properties in a number of polypeptide variants.
\end{abstract}

Keywords: Northern Red-backed Vole, cytochrome $b$ (cytb) gene, isoforms of cytochrome b (Cytb) enzyme, genetic diversity, phylogenetic analysis.

\section{REFERENCES}

Abramson, N. I., Bodrov, S. Yu., 2008. Genetic Differentiation and Phytogeography of Clethrionomys rutilus Pallas, 1811 Inferred from Variation of Mitochondrial Cytochrome b Gene, $11^{\text {th }}$ International Conference "Rodens et Spatium” on Rodent Biology, Myshkin, Russia, July 24-28. Moscow, VTO RAS, 64.

Abramson, N. I., Petrova, T. V., Dokuchaev, N. E., Obolenskaya, E. V., Lissovsky, A. A., 2012. Phylogeography of the Gray Red-Backed Vole Craseomys rufocanus (Rodentia: Cricetidae) Across the Distribution Range Inferred from Nonrecombining Molecular Markers, Russian Journal of Theriology. 11, 2, 137-156. DOI: 10.15298/ rusjtheriol.11.2.04

Agadjanyan, A. K., 1980. The Mammal Fauna of the Pleistocene of Chukotka and the Main Stages of Its Formation, Latest Deposits, and Paleogeography of the Pleistocene of Chukotka. Moscow, Nauka, 256-268 [In Russian].

Bannikova, A. A., Dokuchaev, N. E., Yudina, E. V., Bobretzov, A. V., Sheftel, B. I., Lebedev, V. S., 2010. Holarctic Phylogeography of the Tundra Shrew (Sorex tundrensis) Based on Mitochondrial Genes, Biological Journal of the Linnean Society. 101, 3, 721-746. DOI: 10.1111/j.10958312.2010.01510.x

Chemical Encyclopedia, Ed. by I. L. Knunyants, 1988. Moscow, Encyclopedia, 1 [In Russian].

Chernyavsky, F. B., 1984. Mammals of the Far NorthEast of Siberia. Moscow, Nauka [In Russian].

Cook, J. A., Runck, A. M., Conroy, C. J., 2004. Historical Biogeography at the Crossroads of the Northern Continents: Molecular Phylogenetics of Red-Backed Voles (RODENTIA: Arvicolinae), Molecular Phylogenetics and Evolution. 30, 767-777. DOI: 10.1016/S1055-7903(03)00248-3

Dabrowski, M. J., Pomorski, J. J., Gliwicz, J., 2013. Cytochrome $b$ Gene (cytb) Sequence Diversity in a Microtus oeconomus Population from Białowieża Primeval Forest, Acta Theriologica. 58, 2, 119-126. DOI: 10.1007/ s13364-012-0096-7

Dickson, M., Webb, E., 1982. Enzymes, Moscow, Mir, 2, 735-768 [In Russian].
Gershoni, M., Templeton, A. R., Mishmar, D., 2009. Mitochondrial Bioenergetics as a Major Motive force of Speciation, Bioessays. 31, 642-650. DOI: 10.1002/ bies.200800139

Grigoryeva, O. O.; Stakheyev, V. V.; Orlov, V. N., 2018. Mitochondrial Evidence of Refugial Distribution of the Pygmy Field Mouse Sylvaemus uralensis Pall. (Rodentia, Muridae) in the Northwestern Caucasus, Russian Journal of Genetics. 54, 3, 314-321. DOI: 10.1134/ S1022795418030055

Howell, N., 1989. Evolutionary Conservation of Protein Regions in the Proton Motive Cytochrome b and Their Possible Roles in Redox Catalysis, Journal of Molecular Evolution. 29, 157-169. DOI: 10.1007/ bf02100114

Irwin, D. M., Kocher, T. D., Wilson, A. C., 1991. Evolution of the Cytochrome b Gene of Mammals, Ibid. 32, 128-144.

Iwasa, M. A., Kartavtseva, I. V., Dobrotvorsky, A. K., Panov, V. V., Suzuki, H., 2002. Local Differentiation of Clethrionomys rutilus in Northeastern Asia Inferred from Mitochondrial Gene Sequences, Mammalian Biology. 67, 157-166. DOI: 10.1078/1616-5047-00023

Kocher, T. D., Thomas, W. K., Meyer, A., Edwards, S. V., Paabo, S., Villablanca, F. X., Wilson, A. C., 1989. Dynamics of Mitochondrial DNA Evolution in Animals: Amplification and Sequencing with Conserved Primers, Proceedings of the National Academy of Sciences of the United States of America. 86, 6196-6200. DOI: 10.1073/ pnas.86.16.6196

Koh, H. S., Jang, K. H., In, S. T., Han, E. D., Jo, J. E., Ham, E. J., Jeong, S. K., Lee, J. H., Kim, K. S., Kweon, G. H., 2012. Genetic Distinctness of Sorex caecutiens hallamontanus (Soricomorpha: Mammalia) from Jeju Island in Korea: Cytochrome Oxidase I and Cytochrome b Sequence Analyses, Animal Systematics, Evolution and Divers. 28, 3, 215-219. DOI: http://dx.doi.org/10.5635/ ASED.2012.28.3.215

Kohli, B. A., Fedorov, V. B., Waltari, E., Cook, J. A., 2015. Phylogeography of a Holarctic Rodent (Myodes rutilus): Testing High-Latitude Biogeographical Hypoth- 
eses and the Dynamics of Range Shifts, Journal of Biogeography. 42, 2, 377-389. DOI: 10.1111/jbi.12433

Malyarchuk, B . A., 2011. Adaptive Intraspecific Divergence: an Example Using the Animal Cytochrome $b$ Gene, Russian Journal of Genetics. 47, 8, 979-986. DOI: 10.1134/S1022795411070143

Malyarchuk, B. A., Derenko, M. V., Denisova, G. A., 2015. Mitochondrial Genome Variability in the Wolverine (Gulo gulo), Ibid. 51, 11, 1113-1118. DOI: https://doi. org/10.1134/S1022795415090069

McClellan, D. A., Palfreyman, E. J., Smith, M. J., Moss, J. L., Christensen, R. G., Sailsbery, J. K., 2005. Physicochemical Evolution and Molecular Adaptation of the Cetacea and Artiodactyla Cytochrome $b$ Proteins, Molecular Biology and Evolution. 22, 437-455. DOI:10.1093/molbev/msi028

Pereverzeva, V. V., Primak, A. A., 2015. The Analysis of the Gene Fragment Polymorphism and the Structure of a Part of Cytb of the Red-Backed Vole Myodes rutilus Pallas, 1779, Conference Dedicated to the Memory of Academician K. V. Simakov, Magadan, Nov. 24-25. Magadan, NESC FEB RAS, 148-149 [In Russian].

Pereverzeva, V. V., Primak, A. A., 2016. Genetic Diversity of the Cytochrome $b$ Gene Fragment Haplotypes in Red-Backed Vole Myodes (Clethrionomys) rutilus Pallas, 1779, Genetics Russian Journal. 52, 2, 164-172. DOI: https://doi.org/10.1134/S1022795416020095

Pereverzeva, V. V., Primak, A. A., Dubinin, E. A., 2013b. Phylogenetic Relations of the Northern RedBacked Vole Myodes (= Clethrionomys) rutilus Pallas, 1779 Populations of Northern Priokhotye and the Kolyma Region, Vavilov Journal of Genetics and Breeding. 17, 3, 444-451 [In Russian].

Pereverzeva, V. V., Primak, A. A., Dubinin, E. A., 2014. Genetic Structure of Northern Red-Backed Vole (Myodes (=Clethrionomys) rutilus Pallas, 1779) Populations of the Northern Priokhotye Determined by Sequence Variation of the mtDNA Cytochrome b Gene, Russian Journal of Genetics: Applied Research. 4, 1, 27-34. DOI: 10.1134/ S2079059714010079
Pereverzeva, V. V., Zasypkin, M. Yu., Solovenchuk, L. L., Primak, A. A., Dubinin, E. A., 2011. Variability of Mitochondrial DNA Cytochrome $b$ Gene in the Red Vole Clethrionomys rutilus Pallas, 1779, Population in the Flood-Plain Middle Stream of the Kolyma River, Biology Bulletin. 38, 3, 231-236. DOI: https://doi.org/10.1134/ S1062359011030101

Raspopova, A. A., Shchipanov, N. A., 2011. Variability of a Cytochrome b Region in Different Chromosome Races and Populations of the Common Shrew Sorex araneus L., 1758. Russian Journal of Genetics. 47, 4, 462470. DOI: https://doi.org/10.1134/S1022795411030148

Rausch, R. L., 1963. A Review of the Distribution of Holarctic Recent Mammals, A Symposium, $10^{\text {th }}$ Pacific Science Congress, Honolulu, Hawaii, 1961. Ed. J. Linsley Gressitt. Bishop Museum Press, 29-43.

Shenbrot, G. I., Krasnov, B. R., 2005. An Atlas of the Geographic Distribution of the Arvicoline Rodents of the World (Rodentia, Muridae: Arvicolinae). Sofia, Pensoft Publishing, 336. DOI:10.1016/j. mambio.2006.06.004

Sher, A. V., Giterman, R. E., Zazhigin, V. S., Kiselev, S. $V ., 1977$. New Data on the late Cenozoic Deposits of the Kolyma Lowland, Proceedings of the Russian Academy of Sciences. Geological Series. 5, 69-83 [In Russian].

Tamura, K., Stecher, G., Peterson, D., Filipski, A., Kumar, S., 2013. MEGA-6: Molecular Evolutionary Genetics Analysis Version 6.0., Molecular Biology and Evolution. 30, 2725-2729. DOI: 10.1093/molbev/mst197

Woolley, S., Johnson, J., Smith, M. J., Crandall, K. A., McClellan, , D. A., 2003. TreeSAAP: Selectionon Amino Acid Properties using Phylogenetic Trees, Bioinformatics. 19, 5, 671-672. DOI: 10.1093/bioinformatics/btg043

Yalkovskaya, L. E., Sibiryakov, P. A., Zykov, S. V., 2018. Genetic Variability in the Yellow-Necked Field Mouse (Sylvaemus flavicollis Melch., 1834, Muridae, Rodentia) at the Eastern Border of the Range, Russian Journal of Genetics. 54, 6, 643-651. DOI: https://doi.org/10.1134/ S1022795418060157 